\title{
Nano-Doped Monolithic Materials for Molecular Separation
}

\author{
Caleb Acquah 1,2, Eugene Marfo Obeng ${ }^{3}$, Dominic Agyei ${ }^{4,5}$, Clarence M. Ongkudon ${ }^{3}$, \\ Charles K. S. Moy ${ }^{6}$ and Michael K. Danquah ${ }^{1,2, *}$ \\ 1 Curtin Sarawak Research Institute, Curtin University, Sarawak 98009, Malaysia; \\ caleb.acquah@postgrad.curtin.edu.my \\ 2 Department of Chemical Engineering, Curtin University, Sarawak 98009, Malaysia \\ 3 Biotechnology Research Institute, University Malaysia Sabah, Sabah 88400, Malaysia; \\ eomarfoandy.eom.eom@gmail.com (E.M.O.); clarence@ums.edu.my (C.M.O.) \\ 4 School of Life and Environmental Sciences, Centre for Chemistry and Biotechnology, Deakin \\ University (Waurn Ponds Campus), Geelong 3220, Australia; d.agyei@deakin.edu.au \\ 5 Department of Food Science, University of Otago, Dunedin 9054, New Zealand \\ 6 Department of Civil Engineering, Xi'an Jiaotong-Liverpool University, Suzhou 215123, China; \\ charles.loo@xjtlu.edu.cn \\ * Correspondence: mkdanquah@curtin.edu.my
}

Academic Editor: Zuzana Zajickova

Received: 4 November 2016; Accepted: 18 December 2016; Published: 1 January 2017

\begin{abstract}
Monoliths are continuous adsorbents that can easily be synthesised to possess tuneable meso-/macropores, convective fluid transport, and a plethora of chemistries for ligand immobilisation. They are grouped into three main classes: organic, inorganic, and hybrid, based on their chemical composition. These classes may also be differentiated by their unique morphological and physicochemical properties which are significantly relevant to their specific separation applications. The potential applications of monoliths for molecular separation have created the need to enhance their characteristic properties including mechanical strength, electrical conductivity, and chemical and thermal stability. An effective approach towards monolith enhancement has been the doping and/or hybridization with miniaturized molecular species of desirable functionalities and characteristics. Nanoparticles are usually preferred as dopants due to their high solid phase dispersion features which are associated with improved intermolecular adsorptive interactions. Examples of such nanomaterials include, but are not limited to, carbon-based, silica-based, gold-based, and alumina nanoparticles. The incorporation of these nanoparticles into monoliths via in situ polymerisation and/or post-modification enhances surface adsorption for activation and ligand immobilisation. Herein, insights into the performance enhancement of monoliths as chromatographic supports by nanoparticles doping are presented. In addition, the potential and characteristics of less common nanoparticle materials such as hydroxyapatite, ceria, hafnia, and germania are discussed. The advantages and challenges of nanoparticle doping of monoliths are also discussed.
\end{abstract}

Keywords: monoliths; nanoparticles; copolymerisation; surface modification; doping

\section{Introduction}

Molecular separation is a notable technological development in separation sciences, and the emergence of porous media has created opportunities to advance rapid separation of molecules for process-scale applications. Conventional particulate media rely on diffusional mass transfer through particle pores for molecular separation, and these are mostly suitable and efficient for molecules with hydrodynamic sizes of $<5 \mathrm{~nm}[1,2]$. Depending on the binding chemistry, the particulate beds interact with molecules through electrostatic, hydrophobic, hydrogen bonding, or a combination for 
optimal binding and separation [2]. The microporous characteristics of particulate media typically confer an increased specific surface area and binding capacity for enhanced molecular retention [3]. However, the diffusional mass transfer characteristics associated with particulate adsorbents such as sub-2 $\mu \mathrm{m}$ particles, nanoparticles, and core-shell particles retard the free flow of macromolecular solutes significantly $[4,5]$. Also, the performance and functionality of particulate supports are constantly challenged by subtleties such as diminutive intra-particular void volume, large inter-particular space, slow diffusional transition, prolonged separation time, and low product yield [6,7]. These effects are pronounced especially in the purification of highly concentrated large molecular weight analytes such as proteins, viruses, nucleic acids, and other cellular targets [8], subsequently inducing bed shrinkage, volume swelling, and unwanted channelling along the walls of the column [9]. According to Jungbauer [10], the pores in particulate matrices are insufficiently accessible and the consequent under-utilization reduces separation efficiency and throughput $[11,12]$ which affects process economics significantly. Further, the possible generation of fines, as a consequence of particle abrasion, is another major challenge with particulate sorbents [9].

Monolithic adsorbents have emerged as a suitable replacement for particulate adsorbents in bioseparation, catalysis, optics, and microfluidic applications [13,14]. They are continuous adsorbents with tractable morphological and physicochemical characteristics for tailored applications. The adsorbent can maintain a rigid structural integrity through effective cross-linkages. Monoliths are relatively easy to fabricate and they come in different forms including disks (diameter $>$ length), rods (diameter < length) and annular structures with explicit functionalities [7,15]. The pores of monoliths can be engineered to be mostly micropores, mesopores, and macropores with interconnections and suitable surface chemistries for a wide variety of applications. The interconnected pores limit molecular diffusion to the boundary layer and ensure convective mass transfer of the mobile phase across the continuous stationary phase to improve separation rate, process throughput, and overall efficiency [16,17]. The high external porosity, high permeability, and low pressure drop achievable in monolithic columns have been significant to their efficiency in high throughput separation $[18,19]$.

For polymeric monoliths, Lv et al. [20] reported that challenges with co-polymerisation of monoliths include (i) potential absence of desirable functional groups; (ii) inability to access/activate a large portion of concealed functional groups and (iii) the need to re-optimise polymerisation conditions for different monomer combinations to attain desirable porosity, surface morphology and chemistry. The incorporation of nanoparticles into monolithic matrices via post-modification processes has been demonstrated to be one of the suitable ways to easily overcome the aforementioned challenges $[21,22]$. Owing to the unique properties such as large surface area-to-volume ratio, biocompatibility, susceptible to chemical modification, and other inherent physical, thermal and chemical properties of some nanoparticles, they are able to undergo copolymerisation with suitable monomers to form monoliths $[23,24]$. As a result, monoliths, synthesised with nanoparticle doping through either in situ polymerisation or post-polymerisation surface modification, are embodied with features and properties of the nanoparticles to enhance their performance. Despite the vast availability of varied nanoparticles with different unique properties, limited study has been carried out to explore their potential in enhancing the performance of molecular separation media. This article therefore provides an overview of nano-doped polymer monoliths, challenges and prospects to advance molecular separation.

\section{Monoliths: Preparation, Types, and Applications}

Monoliths are mostly prepared by the agglomeration of molecular subunits via a clustered formation mechanism in the presence of nonreactive porogens to facilitate the formation of controllable channels. The process commences with the formation and growth of nuclei which interact cohesively in a stage-wise manner from the bottom of the mould to produce the continuous monolithic structure. Synthesis of monoliths can be done in bulk or by gradual addition. Different forms of porogens such as 
hydrocarbons [25], ionic liquids [26,27], and supercritical fluids [28], have been used for monolith pore formations. Interestingly, the selective etching of metal carbides has also been demonstrated as a means to form highly ordered pores [29]. It is worth noting that differences in porogens, porogen mixtures, and porogen concentration result in unique pore structure outputs [16].

By convention, monoliths are classified as organic, inorganic and hybrid as shown in Table 1 based on their chemical backbone [30]. Thermal free-radical polymerization is the most commonly used process for synthesizing organic-based monoliths [31,32]. Conversely, inorganic monoliths are synthesized using sol-gel chemistry: transcriptive synthesis, synergistic synthesis, morphosynthesis, and integrative synthesis. In brief, transcriptive synthesis employs the use of self-assembled organic templates; synergistic synthesis relies on the cooperative assembly of templates and building blocks; morphosynthesis is based on spatially restricted reaction fields; and integrative synthesis combines the above-stated approaches [33,34]. The hybrid monolith, per definition, combines features of both the organic and inorganic types.

The organic-based monoliths are typically known for the excellent entrapment of large molecules, whereas silica-monoliths are chiefly used for molecules with smaller hydrodynamic size. The mechanical strength, column efficiency, and stability of silica-based monoliths are perceived to be superior to their organic counterparts [35]. The silica skeleton presents a conglomerate of macropores and mesopores for fast flow and enhanced mass transfer (based on available surface area) respectively. Extensive details of the concepts, syntheses, characterization, modelling, and applications of silica monoliths have been discussed elsewhere by [34].

Table 1. Highlights of selected monolithic materials and applications.

\begin{tabular}{|c|c|c|c|}
\hline Materials & Separation Application & Technique & Reference(s) \\
\hline \multicolumn{4}{|c|}{ Organic } \\
\hline Methacrylate-based & $\begin{array}{c}\text { Polycyclic aromatic } \\
\text { hydrocarbons, caffeine and } \\
\text { several analgesics }\end{array}$ & CEC & [11] \\
\hline Methacrylate-based & Plasmid DNA & AEC & [36] \\
\hline Methacrylate-based & $\begin{array}{l}\text { Ibuprofen and naproxen } \\
\text { enantiomers }\end{array}$ & CEC & [37] \\
\hline Zwitterionic Polymethacrylate-based & Polar analytes & $\begin{array}{l}\text { CEC } \\
\text { HILIC }\end{array}$ & {$[38,39]$} \\
\hline Poly(dimethylsiloxane)-based & - & Microfluidic bioseparation & {$[17,40]$} \\
\hline $\begin{array}{l}\text { Copolymers of glycidyl methacrylate and } \\
\text { ethylene dimethacrylate }\end{array}$ & Chiral separation & HPAC & [41] \\
\hline $\begin{array}{c}\text { Copolymers of butyl methacrylate, } \\
\text { ethylene dimethacrylate, } \\
\text { and 2-acrylamido-2-methyl-1- } \\
\text { propanesulfonic acid }\end{array}$ & Carbohydrates & IEC & [42] \\
\hline \multicolumn{4}{|c|}{ Inorganic } \\
\hline Silica-based & $\begin{array}{l}\text { Chiral phosphinic acid } \\
\text { pseudodipeptides }\end{array}$ & CEC & {$[43]$} \\
\hline Silica-based & Chiral separation & $\mathrm{LC}$ & [44] \\
\hline Silica-based & $\begin{array}{l}\text { Enantioseparation of dansyl } \\
\text { amino acids }\end{array}$ & Ligand Exchange-CEC & [45] \\
\hline Zwitterionic silica-based & $\begin{array}{c}\text { Nucleic acid bases, } \\
\text { nucleosides, } \\
\text { and 2-deoxynucleosides. }\end{array}$ & HILIC & [46] \\
\hline
\end{tabular}


Table 1. Cont.

\begin{tabular}{|c|c|c|c|}
\hline Materials & Separation Application & Technique & Reference(s) \\
\hline \multicolumn{4}{|c|}{ Hybrid } \\
\hline Fused-Silica-Methacrylate-based & $\begin{array}{l}\text { Separation of derivatized } \\
\text { amines and green } \\
\text { fluorescent proteins }\end{array}$ & Microfluidic CEC & [47] \\
\hline Fused-Silica-Polyacrylamide-based & Enantiomer separation & CEC & [48] \\
\hline $\begin{array}{l}\text { Fused-vinylbenzyl } \\
\text { trimethylammonium-cyclodextin-based }\end{array}$ & Acidic compound screening & CEC & [49] \\
\hline$\beta$-Cyclodextrin-silica based & Enantioseparation & $\mathrm{LC}$ & [50] \\
\hline Zwitterionic Organic-Silica-based & Polar compounds & HILIC & [51] \\
\hline
\end{tabular}

In current times, numerous other polymerization techniques have emerged owing to the flexibility in monolith preparation procedures. For instance, direct copolymerization utilizes crosslinking co-monomers which bear the desired functional groups (typically, glycidyl methacrylate, butyl methacrylate, and ethylene dimethacrylate) in a stepwise reaction to obtain favourable surface characteristics $[52,53]$. Frontal polymerization deploys the exothermic heat generated during the polymerization reaction $[54,55]$, whereas radiation polymerization employs electromagnetic waves (e.g., $\gamma$-rays, UV, and microwave) to initiate the polymerization process with high precision and rapidity [56-58]. All these efforts are geared at improving the mechanical robustness, pore size distribution, cross-links, and other surface chemistries which indirectly correlate with process efficiency.

It is worth noting that the mechanical stability and pore size manipulability are driven by factors such as nature and composition of monomers, choice and content of porogen, the temperature of polymerization, type of initiator, and duration of the polymerization. On the other hand, the surface morphology and functionalities of monoliths are tractable through standard grafting procedures such as epoxy, carbonyldiimidazole, disuccinimidylcarbonates, and Schiff-based methods [41,59]. Ligands can be fused to the surface of the monolithic structure to alter the surface chemistry in favour of the target molecule using these methods. The fused ligands (functional groups) render the surface of the monolith polar, hydrophobic, hydrophilic, or reactive and thus contribute to the type and characteristic of the separation column. For instance, in monolithic size-exclusion chromatography (SEC), molecules are separated based on differences in hydrodynamic size, whereas ion exchange chromatography (IEC) capitalizes on disparities in charge densities. However, in high-performance liquid chromatography (HPLC), molecules are classified based on their hydrophobic characteristics, whereas high-interaction liquid chromatography (HILIC) uses zwitterionic functional groups to segregate analytes using their electrostatic interaction. Therefore, the grafted functionality becomes a key dictator of the type and effectiveness of the end applications.

Monolithic steric exclusion chromatography has also been introduced for the purification of large molecules [60]. Based on the mutual steric exclusion of polyethylene glycol (PEG), the technique captures biomolecules (i.e., proteins and viruses) on a non-reactive hydrophilic surface such as hydroxyl-substituted polymethacrylate monoliths [60]. High-performance affinity chromatography (HPAC) and affinity monolith chromatography (AMC) have also emerged [61,62]. These methods employ the use of affinity ligands to selectively separate or analyse constituents of complex samples, for example, chirals [63]. Undoubtedly, the continuous stationary phase of monoliths could also be applied in slalom chromatography (SC), although almost all SC columns are based on particulate beds. The SC technique shares commonalities in packing materials with HPLC [64]; and it relies on hydrodynamic size discrimination $[64,65]$. Unfortunately, the technique remains unpopular in industrial applications but could be given a facelift by the exceptionalities of monoliths. The applications of monolithic adsorbents are increasingly widening and thus, cannot be exhausted 
within the scope of this review. However, recent advancements in monolith technology has heralded a new facet of research in fusion with nanotechnology.

\section{Nano-Doped Monolithic Columns}

Nanoparticles are generally considered as particles within the scale of 1-100 $\mathrm{nm}$ in at least one dimension [30]. They have found application in almost all facet of science, including monolith-based chromatography. The inclusion or synthesis of nanoparticles (NP) into monolithic matrices occurs through either surface modification (Figure 1) or in situ polymerisation processes (Figure 2) to improve the properties of the monolithic solid phase. Of a note, the in situ technique can be grouped into two ways; (i) polymerisation of nanoparticles $[66,67]$ and (ii) copolymerisation of nanoparticles with monomers [68], to form a solo continuous porous networked adsorbent.

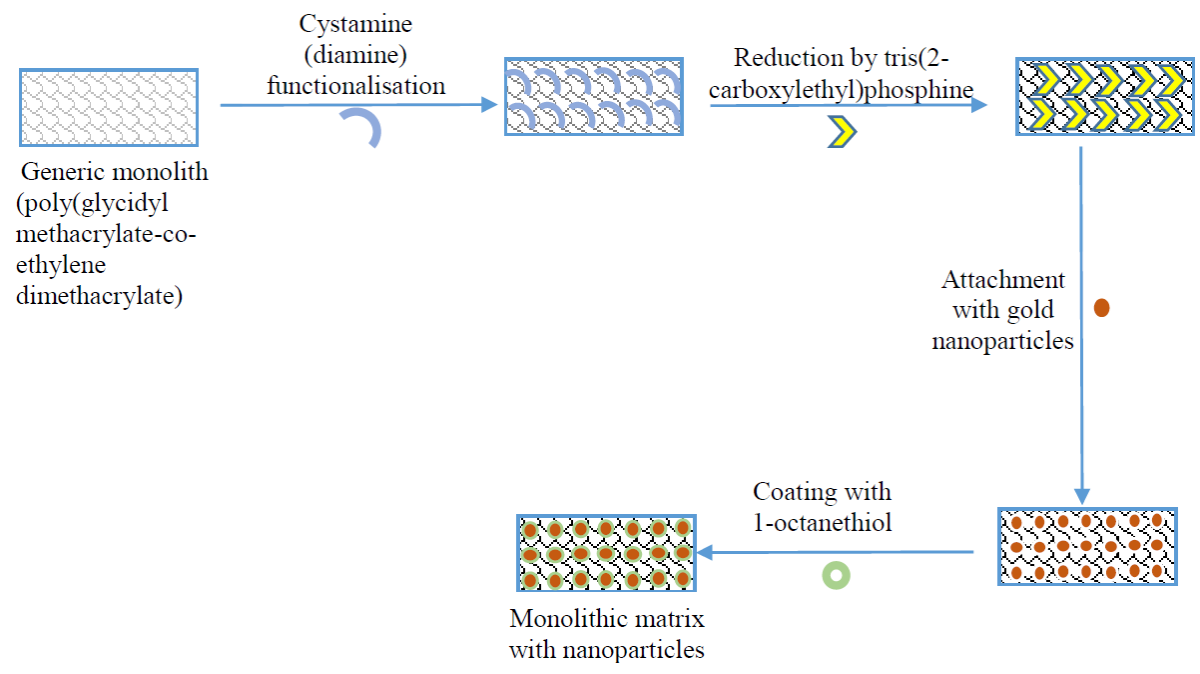

Figure 1. Schematic of the enhancement of monolithic surface with suitable activation chemistries and gold nanoparticles (adapted from [20]).

The structural rigidity, thermal and chemical stabilities, as well as the electrical conductivity of monolithic adsorbents, are easily manipulated with nanoparticles to enhance molecular interaction and other functional characteristics $[19,69,70]$. Also, nanoparticles are capable of extending the specific surface area of monolithic adsorbents to increase retention of test analytes, which leads to an improved selectivity and overall reactivity in the adsorbent [71,72]. According to Alla and Stine [73], the presence of nanoparticles on the surface of monoliths fixes the challenge of limited active sites by permitting high loading of functional groups. Furthermore, the solid-phase-dispersion features of nanoparticles render them suitable for applications involving intermolecular adsorption and interactions. Examples of nanoparticles utilised in the formation of monoliths include carbon-based nanoparticles (C-NP), silver nanoparticles (Ag-NP), gold nanoparticles (Au-NP), alumina nanoparticles (Al-NP), zirconium nanoparticles (Zr-NP), iron nanoparticles (Fe-NP), titanium nanoparticles (Ti-NP) and hydroxyapatite nanoparticles (HA-NP). This section discusses nano-doped monoliths for advanced molecular separation. Also, the advantages and challenges in association with the materials and doping techniques are highlighted. 


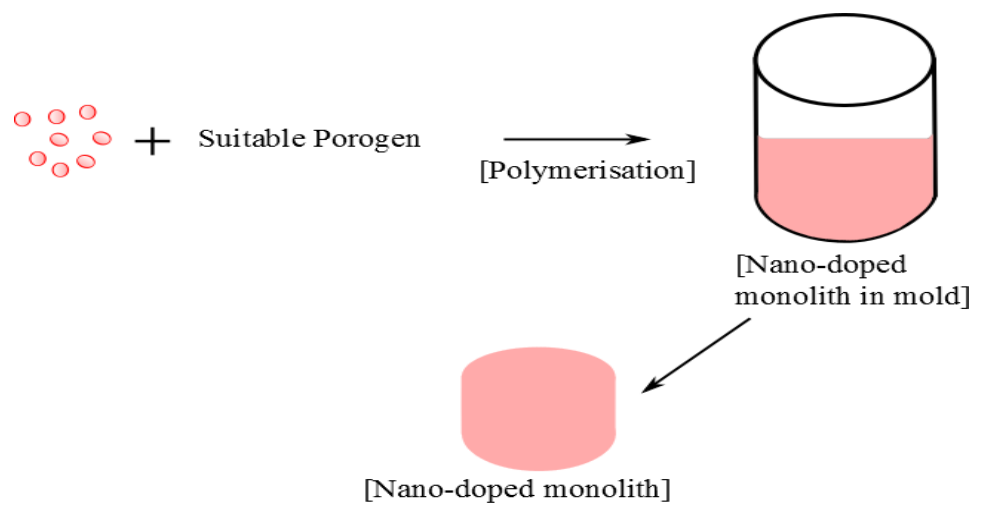

(a)

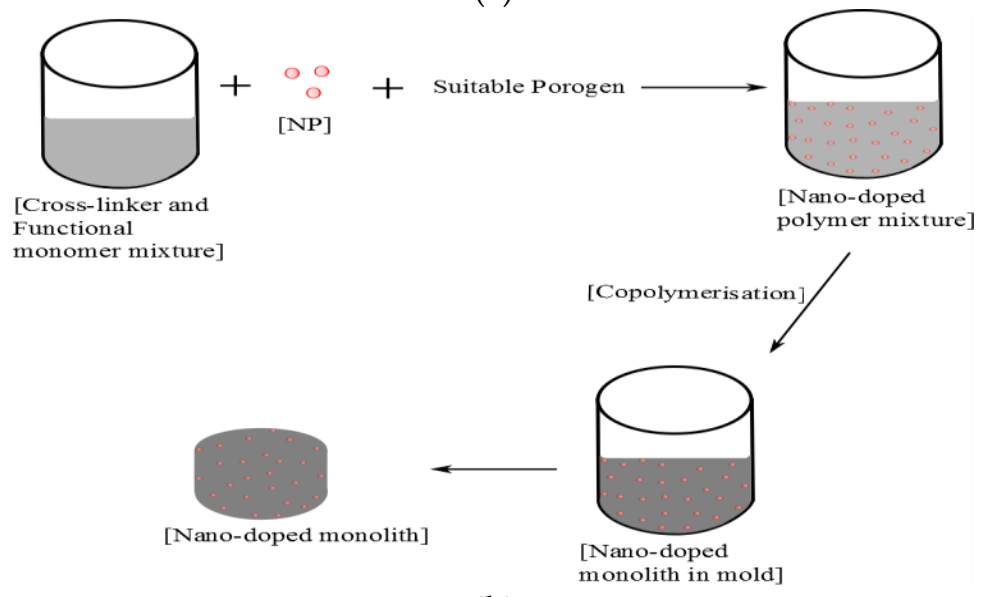

(b)

Figure 2. An example of an in situ approach to the synthesis of a porous monolithic unit. (a) Nano-doped monolith via polymerisation of nanoparticles; (b) Enhanced macroporous monoliths synthesised through copolymerisation of nanoparticles and monomers.

\subsection{Carbon-Based Nanoparticles}

Carbon is a non-metallic, tetravalent element capable of forming single, double, or triple covalent bonds with either itself or with other suitable elements. Carbon-based nanostructures may exist in diverse forms including carbon nanotubes, fullerenes, endohedral fullerenes, nanohorns, nanobuds, nanotori, nano-onions, graphene, and cup-stacked nanotubes [74]. Amongst the aforementioned carbon nanostructures, fullerenes, carbon nanotubes, and graphene, are the most researched $[75,76]$, and have been the main driving force in advancing nanotechnological applications [74,77].

\subsubsection{Carbon Nanotubes}

Carbon nanotubes are unique one-dimensional carbonaceous nanoparticles well known for their structural, electrical, and mechanical properties [78]. These types of carbonaceous NPs can be grouped into two main forms viz., single walled carbon nanotubes (SWNT) and multiwalled carbon nanotubes (MWCNT). Li et al. [79] pioneered the copolymerisation of single wall carbon nanotubes (SWNT) into monoliths to form poly(VBC-EDMA-SWNT) for the successful separation of peptide molecules such as methionine enkephalin, leucine enkephalin, Val-Tyr-Val, angiotensin II, and Gly-Tyr, due to their inherent hydrophobic traits. Navarro-Pascual-Ahuir et al. [80] developed a homogenous monolithic adsorbent doped with carboxy-modified single walled carbon nanotubes via an in situ UV-polymerisation technique. The modified monoliths were successfully used for enantiomeric separation of 3,5-dinitrobenzoyl-(R,S)-leucine and $\mathrm{N}$-acetyl-L-phenylalanine in capillary electrochromatography. Besides copolymerisation of SWNT into the skeletal backbone of polymeric 
monoliths, the former can also be functionalised onto monoliths by means of surface modification through non-covalent interactions [81].

Mayadunne and El Rassi [82] successfully developed multiwalled carbon nanotube (MWCNT) monoliths by means of both copolymerisation and surface modification for the separation and retention of protein molecules. Modulation of protein retention was achieved by varying the amount of MWCNT doped into the monolithic adsorbent. The success of MWCNT-doped monoliths in protein retention was due to the hydrophobic nature and $\pi-\pi$ interactions they establish with proteinaceous targets and aromatic amino acid residues [82]. Similarly, an enhancement in separation performance was obtained in the separation of uracil and alkylbenzenes using poly(GMA-co-EDMA-MWCNT) monoliths and poly(GMA-co-EDMA) monoliths modified with MWCNT [83]. The resultant number of plates observed were as follows: (i) blank poly(GMA-co-EDMA), 1,800 plates/m; (ii) poly(GMA-co-EDMA-MWCNT), 15,000 and 35,000 plates/ $\mathrm{m}$ for flow rates of 1 and $0.15 \mu \mathrm{L} / \mathrm{min}$, respectively; and (iii) surface modified poly(GMA-co-EDMA) using MWCNT, 23,000 plates $/ \mathrm{m}$ at $0.25 \mu \mathrm{L} / \mathrm{min}$. In addition, polymerisation conditions were shown to be influential in determining the separation performance of nano-doped monoliths in their reported work [83]. Zhou et al. [84] illustrated the possible improvement in the surface area from $13.8 \mathrm{~m}^{2} \cdot \mathrm{g}^{-1}$ to $85.5 \mathrm{~m}^{2} \cdot \mathrm{g}^{-1}$, homogeneity and dispersion of monoliths modified with multiwalled carbon nanotubes (MWCNTs) via an oligomer matrix-assisted dispersion method. In addition, there was an improvement in enrichment and adsorption of proteins by 5 -fold relative to the premiere in situ method of incorporating multiwalled carbon nanotubes into monoliths.

However, the challenges with doping monoliths with carbon nanotubes lies in the constrained weighted amount for an enhanced separation performance of small molecules. This was shown in a related development by André et al. [85] using GMA-co-EDMA monoliths copolymerised with MWNT as substrates for the immobilisation of arginase. Although it was observed that an increase in the amount of carbon nanotube to $0.3 \mathrm{wt} \%$ yielded an enhancement in the activity of ariganse to $75 \%$, there were challenges in nanotube dispersion in the polymerisation mixture with signs of crack beyond the optimised $0.3 \mathrm{wt} \%$ [85]. Notably, homogenous dispersion of carbon nanotubes in the polymerisation mixture are often enhanced through the use of selective surfactants or acid oxidative (sulphuric and/or nitric acid) techniques to introduce special functionalities to the tip of an oxidised carbon nanotube [83]. Synthesis of carbon nanotubes are also acknowledged to entail metallic impurities sourced from metallic catalysts [86].

Nevertheless, the use of acid oxidative techniques and surface treatment $[79,87,88]$ of carbon nanotubes (SWNT and / or MWCNT) to increase dispersion are reportedly known to be destructive to the polymer. This is due to their tendency of introducing atomic defects and internal stresses into the nanotube [89]. An alternative dispersion solvent, proposed by Zhang, Gao, Huang and Liu [89], involved a green synthesis technique using mixtures of ionic liquids and deep eutectic solvents for homogeneous dispersion of carbon nanotubes. The green approach was able to achieve an enhanced separation performance for alkyl phenones and benzenes.

\subsubsection{C60-Fullerene}

C60-fullerene are zero-dimensional carbonaceous particles similar to the carbon-nanotubes described above. Needless to say, they have been demonstrated to have relatively higher efficiency in separating small molecules. In addition, their mode of synthesis renders them to be free from impurities such as metals, and they are inherently monodispersed [90]. For instance; Chambers, Holcombe, Svec and Fréchet [53] attained a column efficiency of 85,000 plates $/ \mathrm{m}$ at a linear velocity of $0.46 \mathrm{~mm} / \mathrm{s}$ and a retention factor of 2.6 using fullerene monomer [6,6]-phenyl-C61-butyric acid 2-hydroxyethyl methacrylate ester (PCB-HEM). This was found to be 18 fold higher than the blank poly(GMA-co-EDMA). A remarkable improvement exceeding 110,000 plates/m at a linear velocity of $0.32 \mathrm{~mm} / \mathrm{s}$ and a retention factor of 4.2 was attainable when PCB-HEM monomer was incorporated into the synthesis of poly(BMA-co-EDMA) by the same group. 
Kubo et al. [91] developed a technique for the immobilisation of a conjugated C60-fullerene (NHS-PFPA-C60) onto the surface of silica monoliths modified with 3-aminopropyltrimethoxysilane (APTMS). Modification with APTMS introduced amino moieties into the polymeric silica monolith which enabled interactions with NHS-functional ends of C60-fullerene.

\subsubsection{Graphene (GN) and Graphene Oxide (GO)}

These are unique two-dimensional carbonaceous nanoparticles possessing a high specific surface area (theoretical limit: $2630 \mathrm{~m}^{2} \cdot \mathrm{g}^{-1}$ ), loading capacity, ease of modification and $\pi-\pi$ electrostatic stacking suitable for molecular separations as compared to their rival carbon nanotubes $[86,92,93]$. Graphene-based nanoparticles are easily synthesised at a large scale; are deemed economical for mass-scale production, and have a wider scale of application due to the presence of functional groups in their domain [86]. These properties inherently make graphene (GN) and graphene oxide (GO) superior or suitable doping particles over their analogous carbonaceous counterparts.

Wang and Yan [94] developed a green approach for capillary electrochromatographic monoliths copolymerised with GO at room temperature for the separation of alkyl benzenes and polycyclic aromatics. In the aforementioned work, GO was monodispersed in cyclohexanol without the need for treatment due to its reactivity. It was observed that blank monoliths, poly(MAA-co-EDMA) had lower retention times as compared to their poly(GO-MAA-co-EDMA) counterparts.

Besides the green approach by Wang and his group, Tong, Liu, Li, Zhou, Jia, and Duan [93] utilised a thermally initiated free-radical approach for the synthesis of a poly(BMA-co-EDMA) copolymerised with graphene nanosheets. Similarly, it was revealed that the extraction of nine varieties of glucocorticoids was improved due to hydrophobic, $\pi-\pi$ stacking and hydrogen bonding interactions.

An outstanding trend in the recent application of graphene nanoparticles is in the fabrication of graphene aerogel-based monoliths unlike the mainstream co-polymerisation of nanoparticles with monomers $[66,67,95,96]$. For instance; Huang, Chen, Zhang, Lu, and Zhan [67] used glucone- $\delta$-lactone as gel promoter in the presence of either a metal ion or polyamine cross-linker to form an aerogel monolith. This group of modified aerogels has been shown intrinsically to have better mechanical stability and performance, as well as chemical reactivity over conventional aerogels due to the use of graphene whilst maintaining characteristic traits of the conventional aerogels such as high porosity, permeability, and surface-to-volume ratio.

\subsection{Silver Nanoparticles (AgNPs)}

Silver nanoparticles (AgNPs) have gained a surge in research interest for a plethora of applications owing to their versatility in being biocompatible, less toxic, easy to fine-tune into diverse morphologies, as well as possessing antimicrobial, optical, biosensing, and cryogenic abilities [97-99]. These inherent characteristics are governed by their physical morphology and surface functionality [100]. Conventional synthesis technique for AgNPs is primarily through the wet-chemical reduction of silver ions in the presence of reducing agents [97]. The disadvantage of this approach is the resultant agglomeration of the particles. An alternative technique is by means of plant extracts and microorganisms biosynthesis [101]. Benefits in the biosynthesis technique include eco-friendliness, being relatively economical, and the ability to act as capping and reducing agents $[97,101]$.

Zhu, Morisato, Li, Kanamori, and Nakanishi [99] developed a facile technique to homogeneously modify the surface of hierarchically porous silica monoliths with non-charged AgNPs using ethanol and formaldehyde as reducing agents. It was shown that the use of ethanol as a reducing agent resulted in better homogeneity of AgNPs in the porous structure of the silica monolith as compared to the conventional formaldehyde. In addition, the AgNP-surface modified silica monoliths produced were efficient in the separation of diverse forms of aromatic hydrocarbons based on their number of aromatic rings and isomeric configuration [99,102]. That notwithstanding, a higher percentage of AgNPs loading $(11.95 \mathrm{wt} \%)$ onto the surface of silica monoliths was demonstrated by Yu et al. [103] through the use of ethylene glycol reduction as compared to $9.34 \mathrm{wt} \%$ for ethanol reduction after modification with an 
amine reagent for both cases. This higher loading effect was ascribed to the active-reaction ethylene glycol has on the silver-amine complex formed. It was also obvious from their analysis that there were physical changes in colour from white to deep-dark and light-dark for silica-monoliths upon doping with AgNPs using ethanol and ethylene glycol reducing agents, respectively.

Another enhanced application through the use of AgNP-modified monoliths has been in the field of surface enhanced Raman scattering (SERS). The success has been attributed to the exceptional convective mass flow of fluids in monoliths, the capacity of the composite structure to direct metal nanostructures, the tuneable pore size, and high surface area enabling an enhanced interaction between target and SERS active surfaces [104,105]. In light of this, an AgNP-modified monolithic substrate for SERS was developed by Liu, White, and DeVoe [104] for a label-free detection of peptide bradykinin and cytochrome c. In addition, it was shown from their analysis that the copolymerisation of AgNP with acrylic-based polymeric monoliths synthesised by means of UV-radiation yielded low sensitivity in the detection of Rhodamine 6G (R6G dye) as compared to an AgNP-surface modified hydrophobic BMA-co-EDMA and GMA-co-SR454. Notably, the latter had a higher sensitivity towards R6G amongst the three set of analysis [104]. Nevertheless, Navarro-Pascual-Ahuir, Lerma-García, Ramis-Ramos, Simó-Alfonso, and Herrero-Martínez [30] demonstrated that doping of AgNP into LMA-monoliths via copolymerisation or surface modification both led to changes in the chromatographic properties, relative to an unmodified LMA-monolith. In addition, their separation performance was observed to be relatively similar under optimised conditions for a capillary electrochromatographic application [30]. Pan, Guo, Zhu, Wang, Zhang, Kang, Wu, and Du [105] also recently developed a surface-enhanced Raman scattering (SERS) capillary column by means of modifying poly(GMA-co-EDMA) monoliths with amino functional groups followed by immobilisation with colloidal AgNPs. The newly developed SERS capillary substrate was able to detect the presence of 4-mercaptopyridine (4-Mpy) and Rhodamine $6 \mathrm{G}$ with a detection limit of 100 and $10 \mathrm{pM}$, respectively, with an enhancement factor of $1.2 \times 10^{8}$.

Aydoğan and El Rassi [106] developed a fumed nanosilica-doped monolithic column for hydrophilic separations of small polar molecules such as nucleosides, nucleotides, and hydroxybenzoic acids. The fumed-silica nanoparticles were produced by means of continuous flame hydrolysis of silicon tetrachloride in an oxyhydrogen gas flame at $1000^{\circ} \mathrm{C}$. The hydrophilic monolith was prepared by means of copolymerising monomers; glyceryl monomethacrylate (GMM), and ethylene dimethacrylate (EDMA), with fumed nano-silica particles [106]. Therein, various in process polymerisation conditions were experimented including the type of biporogens and ratio of monomers to AgNP, in addition to the level of $\mathrm{pH}$ for the mobile phase. Better hydrophilic separation performances were attained compared to previously synthesised GMM-co-EDMA blank polymeric monoliths [82]. Thereafter, the same group of El Rassi further developed a newly hybridised methacryloyl fumed silica nanoparticle (MFSNP) monomer by modifying 3-(trimethoxysilyl)propylmethacrylate (TMSPM) with fumed silica nanoparticles (FSNP) [107]. The resultant MFSNP monomer was then copolymerised with GMM and EDMA to produce a poly(GMA-EDMA-MFSNP) monolith followed by surface modification with octadecyl ligands. This yielded octadecyl-functionalised hybrid-monoliths with hydrophobic interactions under conditions of reversed phase elution [107]. The newly formed hybridised-monoliths were able to successfully separate standard protein molecules such as lysozyme, ribonuclease A, carbonic anhydrase isozyme II, cytochrome $\mathrm{C}$, $\alpha$-chymotrypsinogen $\mathrm{A}$ and myoglobin within $10 \mathrm{~min}$ with a flow rate of $1.0 \mathrm{~mL} / \mathrm{min}$.

\subsection{Gold Nanoparticles (AuNPs)}

AuNPs are stable, readily available and biocompatible metallic nanoparticles which possess a high surface-to-volume ratio and are easy to modify with different functional groups (amino, thiol and/or cyano) $[20,108]$. Due to their intrinsic characteristics, AuNPs have been incorporated in the development of a number of bio-applications over the years [109-113]. It is, however, evident that in their incorporation into monolithic adsorbents and applications, surface modification are primarily preferred over copolymerisation approaches [92]. This is so, in order to avoid occurrences leading to 
the swallowing of the nanoparticle into the monolith matrix with little or no portions of the former available to be modified [92].

For instance; one of the very first works in the attachment of AuNPs onto the surface of poly(BuMA-co-EDMA) monolithic adsorbents was conducted by the group of Connolly et al. [114]. This was successfully achieved by means of hydrogen abstraction of azlactone monomers from the pore surface of poly(BuMA-co-EDMA). Thereafter, cysteamine and ethylenediamine were used in separate experiments to introduce pendant amino and thiol functional groups, respectively, into the monolith, followed by immobilisation of AuNPs. Despite the success of this protocol, steric hindrance during the immobilisation of AuNPs may occur leading to the reduction of its immobilisation density. This is due to the bifunctional nature of both cysteamine and ethylenediamine which could lead to the formation of crosslinks when they react with epoxy or azlactone functional groups of the monolith [20]. An improved approach is via reaction mechanisms that utilise tris(2-carboxylethyl)phosphine leading to the reduction in disulphide bonds [20,22].

Chen, Deng, Wu, Liang, Jiang, Yang, Liang, Zhang, and Zhang [22] introduced gold nanoparticles onto the surface of pores in poly(GMA-co-PEGDA) monolithic adsorbents to form a poly(GMA-co-PEGDA)-Au monolith. This was subsequently followed by immobilisation of thrombin-binding aptamers. Chemistries leading to the introduction of thiol moieties onto the surface of the synthesised blank monolith were used in order to immobilise gold nanoparticles. The use of PEGDA minimised non-specific adsorption by the adsorbent. Compared to other organic monoliths the introduction of gold nano-particles could be said to have enhanced coverage density from $164 \mathrm{~mol} / \mu \mathrm{L}$ [115] to the reported $277.1 \mathrm{~mol} / \mu \mathrm{L}$ by Chen, Deng, Wu, Liang, Jiang, Yang, Liang, Zhang, and Zhang [22]. Nevertheless, this value fell short of the coverage density $568 \mathrm{~mol} / \mu \mathrm{L}$ reported by Deng et al. [116] for using organic-silica based monoliths for the immobilisation of thrombin aptamers.

Converse to the afore-described protocol [22], poly(GMA-co-EDMA) monolithic adsorbents were synthesised by the group of Vergara-Barberán et al. [117] followed by pulverisation and sieving to obtain sizes less than $\leq 100 \mu \mathrm{m}$. These particles were then functionalised with ammonia prior to the immobilisation of AuNPs. The obtained modified poly(GMA-co-EDMA)-AuNP were applied in the separation of protein samples; bovine serum albumin, cytochrome c, and lectins in European mistletoe leaves, based on their $\mathrm{pI}$.

\subsection{Alumina Nanoparticles}

Alumina $\left(\mathrm{Al}_{2} \mathrm{O}_{3}\right)$ nanoparticles have also found a considerable application in monolith technology. Arguably, their success has been the result of the high porosity and surface-volume ratio, high adsorptivity, and dispersibility in organic solvents, as well as the hydroxyl functional group, which together render them suitable for incorporation into sorbents for separation processes $[118,119]$. For instance; Li, Zhou, Tong, and Jia [119] by means of a copolymerisation technique developed poly(NIPAAm-coMBAAm- $\mathrm{Al}_{2} \mathrm{O}_{3}$ ) for the detection of synthetic dyes such as Tartrazine, Sunset Yellow, Allura Red, Azorubine in food. An optimised amount of alumina particles in the copolymerisation process was able to result in the minimisation of swelling in the monolith, reduce the back pressure, and enhance the surface area. Similarly, Zhang, Chen, Tian, Li, Quan, and Jia [118] applied the same approach to develop a poly(MAA-co-EGDMA- $\mathrm{Al}_{2} \mathrm{O}_{3}$ ) monolith in a microfluidic chip for the detection of 2-amino-4-chlorophenol in chlorzoxazone tablets. It was evident from their physicochemical characterisation via FT-IR and SEM analysis that their copolymerisation process was a success. The obtained limit of detection and quantification were 2.8 and $9.1 \mathrm{mg} \cdot \mathrm{L}^{-1}$, respectively. In addition, other reports have also been established in the use of alumina particles as monomeric units (raw materials) in the synthesis of monolithic adsorbents for the control of flue gases [120]. Contrary to the copolymerisation/polymerisation protocols described above, Li et al. [121] modified the epoxide functional groups on the surface of poly(NIPAAm-co-GMA-co-EDMA) using an optimised amount of $\mathrm{NaOH}$ with homogeneously dispersed $\gamma-\mathrm{Al}_{2} \mathrm{O}_{3}$ nanoparticles. The obtained poly(NIPAAm-co-GMA-co-EDMA)- $\mathrm{Al}_{2} \mathrm{O}_{3}$ monoliths were used for the enrichment of Sudan dyes in 
red wine samples. It was observed that the optimised parameters were effective in enhancing the mechanical stability and performance of the modified monolith. The interaction between $\gamma-\mathrm{Al}_{2} \mathrm{O}_{3}$ nanoparticles dispersed in $\mathrm{NaOH}$ and the epoxide functional groups of the monolith were based on nucleophilic substitution.

\subsection{Zirconia $\left(\mathrm{ZrO}_{2}\right)$ Nanoparticles}

Zirconia nanoparticles are intrinsically amphoteric with a wide range of $\mathrm{pH}$ resistivity on the surface and can undergo reversible reactions based on Lewis acid-base interaction as shown in reaction Equations (1) and (2). In addition, they have a high affinity for anions [122,123].

$$
\begin{gathered}
\mathrm{ZrOH} \leftrightarrow \mathrm{ZrO}^{-}+\mathrm{H}^{+} \\
\mathrm{ZrOH}_{2}^{+} \leftrightarrow \mathrm{ZrOH}+H^{+}
\end{gathered}
$$

Previous attempts to synthesise zirconia-based monoliths resulted in pellets due to the rapid hydrolysis rate of zirconia alkoxides [124]. The rapid hydrolysis rate renders zirconia alkoxides difficult to handle. In order to curtail this effect and form homogenous macroporous monoliths, it had been revealed that the inclusion of acetic acid in the complexation ratio during sol-gel synthesis resulted in a slower hydrolysis, longer gelation time, and the formation of chelates [125]. Based on this positive outcome, Park's group developed a number of capillary electrochromatographic (CEC) protocols using zirconia-based monoliths with cellulose tris(3,5-dimethylphenylcarbamate)-modified surfaces for the enantiomeric separation of racemic compounds [126] as well as basic chiral compounds in an acidic media [126] and basic media [127]. Similarly, phosphate $\beta$-cyclodextrins, due to their anionic charge and Lewis basic phosphate reactive groups, were functionalised onto the Lewis acid groups on the surface of zirconia monoliths for chiral separations of Metoprolol, Sertraline, Citalopram, and Atenolol [128]. Other types of zirconia alkoxide-based monoliths include zirconia aerogels [129], HILIC mode zirconia monoliths [130], and hybrid silica-zirconia monoliths [131,132].

The adverse effect of using Zirconia alkoxides and sol-gel technique for the formation of zirconia oxide nanoparticles are the often unsuitable crystallinity, poor solubility and stability, laborious approach, as well as challenges with size distribution [133-135]. In lieu of zirconia alkoxides, Liu et al. [136] recently developed an alternate approach using zirconium trifluoroacetate in oleylamine to annihilate the consequential impacts of the latter. The reaction mechanism followed an irreversible amidization-assisted sol-gel route as shown in Equation (3) with a yield $>90 \%$.

$$
\begin{array}{r}
\mathrm{Zr}\left(\mathrm{CF}_{3} \mathrm{COO}\right)_{4} \rightarrow \mathrm{ZrO}_{2} \\
\text { Oleylamine }>90 \%
\end{array}
$$

\subsection{Iron Oxide Nanoparticles}

Iron oxide nanoparticles could be in two different molecular forms; magnetite $\left(\mathrm{Fe}_{3} \mathrm{O}_{4}\right)$ and maghemite $\left(\gamma-\mathrm{Fe}_{2} \mathrm{O}_{3}\right)$. Krenkova and Foret [21] developed a poly(GMA-co-EDMA) monolithic column with iron oxide nanoparticles immobilised unto its surface, for the selective enrichment of phosphopeptides prior to mass spectrometry. The chemistry between iron oxide nanoparticles and poly(GMA-co-EDMA) monolith surface was made possible by functionalising the latter with quaternary amines, followed by iodoethane and nitromethane. The binding capacity obtained from their analysis of adenosine- $5^{\prime}$-triphosphate was $86 \mathrm{mmol} / \mathrm{mL}$ column volume, which happens to be approximately 61-fold higher than the immobilized metal ion affinity chromatography based on titanium ions for synthetic phosphopeptides YKVPQLEIVPNSpAEER [137]. Notably, the synthesis of iron oxide nanoparticles utilised in their approach was by means of a coprecipitation procedure involving $\mathrm{Fe}(\mathrm{II})$ and $\mathrm{Fe}(\mathrm{III})$ leading to the formation of a mixture of $\mathrm{Fe}_{3} \mathrm{O}_{4}$ and maghemite $\gamma-\mathrm{Fe}_{2} \mathrm{O}_{3}$. Nonetheless, stability of the synthesised nanoparticles was ensured by using citrate 
ions. Using a similar approach, iron oxide nanoparticles were immobilised onto the surface of poly(HEMA-co-EDMA) synthesised in a pipette tip to render them suitable for proteomic studies [138]. The modified pipette assay was able to enrich phosphopeptides from tryptic digests of $\alpha$ - and $\beta$-caseins [138]. A previous report by Smirnov et al. [139] on the synthesis of poly(divinylbenzene-co-ethylvinylbenzene-co-2-hydroxyethyl methacrylate) revealed that an increase in the molar fraction of HEMA had a consequential impact on the increase of the surface area, the reduction of eddy dispersion, and the low resistance to fluid flow.

\subsection{Titanium $\left(\mathrm{TiO}_{2}\right)$ Nanoparticles}

Titania nanoparticles are characterised by wider $\mathrm{pH}$ resistance relative to silica monoliths, biocompatibility, thermal and mechanical stability capable of binding phosphorylated proteins and peptides $[140,141]$. Despite these unique features, the challenge in incorporating titania into monoliths as a chromatographic adsorbent include their fast hydrolysis/condensation kinetics, denaturing of proteins from isopropyl alcohol byproducts, and mechanisms to control and engineer pore formation [142,143]. A technique to overcome these setbacks was attempted by Chen, Yi, Brennan, and Brook [142] through the introduction of glycerol and high molecular weight poly(ethylene oxide) to control the kinetic reactions, phase separations, and pore formation of titania monoliths. Some of the other reported techniques utilised in the preparation of titanium monoliths include; (i) sol-gel [144]; phase separation induced [145]; template free sol-gel process with phase separation [146]; templated sol-gel process [147]. Černigoj, Gašperšič, Fichtenbaum, Lendero Krajnc, Vidič, Mitulović, and Štrancar [140] recently created a methacrylate based monolith with immobilised $\mathrm{TiO}_{2}$ nanoparticles for the enrichment of phosphorylated peptides under low salt concentrations and wide $\mathrm{pH}$ variation. Another form of titania monoliths also used for the enrichment of phosphorylated proteins is an aerogel monolith developed by Sui, Liu, Lajoie, and Charpentier [28] using supercritical carbon dioxide. The use of supercritical fluid is known to improve the wettability, enhance mass transfer and annihilate the occurrence of shrinkage due to the absence of surface tension [28].

\subsection{Hydroxyapatite Nanoparticles (HA-NP)}

Hydroxyapatite $\left[\mathrm{Ca}_{5}\left(\mathrm{PO}_{4}\right)_{3}(\mathrm{OH})\right]$ nanoparticles are also bioactive materials suitable for the selective enrichment of phosphorylated proteins and peptides, but are deficient in mechanical strength [148]. According to Yang, Ning, Xiao, Chen, and Zhou [23], HA nanoparticles inherently have positive and negative charges as a result of the presence of calcium and phosphate ionic sites, respectively. This further enhances their use as chromatographic adsorbent materials in the separation of viral and proteinaceous targets. Yu et al. [149] constructed a miniaturised monolithic column with immobilised HA nanoparticles for rapid extraction of DNA molecules under optimised conditions of $\mathrm{pH}$, ion type and concentration, and loading capacity. The optimised conditions and low salt requirement during the DNA extraction process enabled PCR amplification of PBE2 plasmid from Bacillus subtilis crude lysate. In addition, an HA monolithic column via copolymerisation of poly(2-hydroxyethyl methacrylate-co-ethylene dimethacrylate) for the separation of protein molecules such as ovalbumin, myoglobin, lysozyme, and cytochrome $\mathrm{c}$ as well as enrichment of phosphorylated peptides was demonstrated $[138,150]$. Figure 3 is an illustration of selected applications for the different nano-doped monoliths reported in Section 3. 


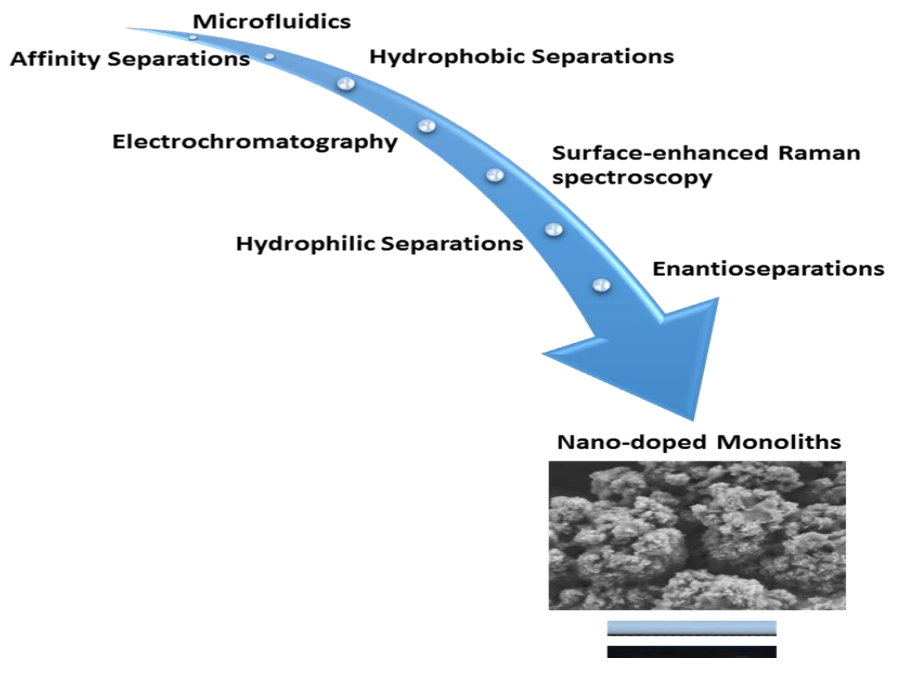

Figure 3. Selected applications of nano-doped monoliths.

\section{Future Advances in Nano-Doped Monolith Synthesis}

There exist a plethora of nanoparticles with diverse properties yet to be fully explored to enhance monolithic adsorbents in molecular separations. Some of these potential nanoparticles include but are not limited to cerium oxide, hafnium oxide, magnesium oxide, and germanium oxide. Of note, these potential nanoparticles possess similar properties and challenges as some of the already implemented nanoparticles discussed in Section 3. Despite their associated inherent challenges, they have been successfully synthesised and incorporated in other biotechnological applications; hence, their prospects for being introduced into monolithic adsorbents. For instance; the challenges in the use of germania-based nanoparticles are the rapid rate of reactivity, hydrolysis, and condensation, which result in nanoparticles with heterogeneous structures. Nevertheless, they have been successfully constructed as porous germanates for applications such as gas adsorption and ion exchange [151-153]. The presence of oxygen functional groups on these nanoparticles renders them suitable for activation in the construction of a biomolecule-nanoparticle-monolithic support immobilisation system. Table 2 lists the properties and reported applications of prospective nanoparticles in monolith synthesis.

Table 2. Highlights of potential nanoparticles and their attributes for monolith incorporation.

\begin{tabular}{|c|c|c|c|}
\hline Nano-Particles & Properties & Remark & Reference(s) \\
\hline Cerium oxide $\left(\mathrm{CeO}_{2}\right)$ & $\begin{array}{l}\text { Have a high surface } \\
\text { area-to-volume ratio, reactive } \\
\text { sites, possess free radicals, have } \\
\text { a shielding activity and serve as } \\
\text { effective antioxidants. }\end{array}$ & $\begin{array}{l}\text { Utilised as chromatographic packing } \\
\text { materials for normal phase separation } \\
\text { of polycyclic aromatic hydrocarbons as } \\
\text { well as C60 and C70 fullerenes. } \\
\text { Have promising features over } \\
\text { silica-based nanoparticles. }\end{array}$ & [154-156] \\
\hline Magnesium oxide $(\mathrm{MgO})$ & $\begin{array}{l}\text { Have high adsorptivity, devoid } \\
\text { of toxicity, and limited } \\
\text { hydrophilic capacity. }\end{array}$ & $\begin{array}{l}\text { For the adsorption of } \\
\text { organophosphorus compounds, } \\
\text { fluorides, azo and anthraquinone } \\
\text { reactive dyes, as well as having } \\
\text { bactericidal activity. }\end{array}$ & [158-160] \\
\hline
\end{tabular}




\section{Conclusions}

Monoliths have been widely demonstrated as suitable adsorbents for the fast, tuneable, and cost-effective chromatographic separation of molecules. Despite the exponential increase in their applications, they are fraught with a number of application setbacks, such as the likely absence of desirable functional groups; inability to access/activate a large portion of concealed functional groups, and the need to always re-optimise polymerisation conditions for each new monomer combination to attain desirable porosity, surface morphology, and chemistry. An emerging way to overcome these challenges has been demonstrated through the doping of monolithic matrices with nanoparticles by means of either copolymerisation or surface modification. The introduction of nanoparticles, such as silver, graphene, carbon nanotubes, fullerene, hydroxyapatite, and iron nanoparticles has been shown to enhance the surface area-to-volume ratio, electrical conductivity, robustness, together with the thermal and chemical stabilities. In addition, the inherent ability to chemically modify nanoparticles with desirable functional groups broadens the application scope of nano-doped monoliths. That notwithstanding, there has been limited studies into various ways of optimising the merger of nanomaterials with monolith science. Although there exists a plethora of nanomaterials, most studies have been geared towards carbonaceous, silver, and gold nanoparticles in relation to doping of monoliths. Owing to the properties of nanoparticles, nano-doped monoliths are viable options through which chromatographic applications can be easily enhanced.

Conflicts of Interest: The authors declare no conflict of interest.

\section{References}

1. Tyn, M.T.; Gusek, T.W. Prediction of diffusion coefficients of proteins. Biotechnol. Bioeng. 1990, 35, 327-338. [CrossRef] [PubMed]

2. Tan, M.X.L.; Agyei, D.; Pan, S.; Danquah, M.K. Parametric investigation of batch adsorption of proteins onto polymeric particles. Curr. Pharm. Biotechnol. 2015, 16, 816-822. [CrossRef] [PubMed]

3. Jungbauer, A.; Hahn, R. Polymethacrylate monoliths for preparative and industrial separation of biomolecular assemblies. J. Chromatogr. A 2008, 1184, 62-79. [CrossRef] [PubMed]

4. Ahmad, I.A.H.; Soliven, A.; Allen, R.C.; Filgueira, M.; Carr, P.W. Comparison of core-shell particles and sub-2 $\mu \mathrm{m}$ fully porous particles for use as ultrafast second dimension columns in two-dimensional liquid chtomatography. J. Chromatogr. A 2015, 1386, 31-38. [CrossRef] [PubMed]

5. Gritti, F.; Leonardis, I.; Abia, J.; Guiochon, G. Physical properties and structure of fine core-shell particles used as packing materials for chromatography: Relationships between particle characteristics and column performance. J. Chromatogr. A 2010, 1217, 3819-3843. [CrossRef] [PubMed]

6. Svec, F.; Tennikova, T.B.; Deyl, Z. Monolithic Materials: Preparation, Properties and Applications; Elsevier: Amsterdam, The Netherlands, 2003; Volume 67.

7. Roberts, M.W.; Ongkudon, C.M.; Forde, G.M.; Danquah, M.K. Versatility of polymethacrylate monoliths for chromatographic purification of biomolecules. J. Sep. Sci. 2009, 32, 2485-2494. [CrossRef] [PubMed]

8. Acquah, C.; Moy, C.K.S.; Danquah, M.K.; Ongkudon, C.M. Development and characteristics of polymer monoliths for advanced LC bioscreening applications: A review. J. Chromatogr. B 2016, 1015-1016, 121-134. [CrossRef] [PubMed]

9. Noel, R.; Sanderson, A.; Spark, L. A monolithic ion-exchange material suitable for downstream processing of bioproducts. In Ion Exchange Advances; Springer: Berlin, Germany, 1992; pp. 229-236.

10. Jungbauer, A. Chromatographic media for bioseparation. J. Chromatogr. A 2005, 1065, 3-12. [CrossRef] [PubMed]

11. Chirica, G.S.; Remcho, V.T. Fritless capillary columns for HPLC and CEC prepared by immobilizing the stationary phase in an organic polymer matrix. Anal. Chem. 2000, 72, 3605-3610. [CrossRef] [PubMed]

12. Ghose, S.; Forde, G.M.; Slater, N.K. Affinity adsorption of plasmid DNA. Biotechnol. Prog. 2004, 20, 841-850. [CrossRef] [PubMed] 
13. González-González, M.; González-Valdez, J.; Mayolo-Deloisa, K.; Rito-Palomares, M. Monolithic chromatography: Insights and practical perspectives: Monolithic chromatography: Insights and practical perspectives. J. Chem. Technol. Biotechnol. 2016, 92. [CrossRef]

14. Knob, R.; Sahore, V.; Sonker, M.; Woolley, A.T. Advances in monoliths and related porous materials for microfluidics. Biomicrofluidics 2016, 10, 032901. [CrossRef] [PubMed]

15. Ongkudon, C.M.; Kansil, T.; Wong, C. Challenges and strategies in the preparation of large-volume polymer-based monolithic chromatography adsorbents. J. Sep. Sci. 2014, 37, 455-464. [CrossRef] [PubMed]

16. Danquah, M.K.; Forde, G.M. Preparation of macroporous methacrylate monolithic material with convective flow properties for bioseparation: Investigating the kinetics of pore formation and hydrodynamic performance. Chem. Eng. J. 2008, 140, 593-599. [CrossRef]

17. Chan, A.S.; Danquah, M.K.; Agyei, D.; Hartley, P.G.; Zhu, Y. A parametric study of a monolithic microfluidic system for on-chip biomolecular separation. Sep. Sci. Technol. 2014, 49, 854-860. [CrossRef]

18. Díaz-Bao, M.; Barreiro, R.; Miranda, J.M.; Cepeda, A.; Regal, P. Recent advances and uses of monolithic columns for the analysis of residues and contaminants in food. Chromatography 2015, 2, 79-95. [CrossRef]

19. Zhang, Z.; Wang, Z.; Liao, Y.; Liu, H. Applications of nanomaterials in liquid chromatography: Opportunities for separation with high efficiency and selectivity. J. Sep. Sci. 2006, 29, 1872-1878. [CrossRef] [PubMed]

20. Lv, Y.; Alejandro, F.M.; Fréchet, J.M.; Svec, F. Preparation of porous polymer monoliths featuring enhanced surface coverage with gold nanoparticles. J. Chromatogr. A 2012, 1261, 121-128. [CrossRef] [PubMed]

21. Krenkova, J.; Foret, F. Iron oxide nanoparticle coating of organic polymer-based monolithic columns for phosphopeptide enrichment. J. Sep. Sci. 2011, 34, 2106-2112. [CrossRef] [PubMed]

22. Chen, Y.; Deng, N.; Wu, C.; Liang, Y.; Jiang, B.; Yang, K.; Liang, Z.; Zhang, L.; Zhang, Y. Aptamer functionalized hydrophilic polymer monolith with gold nanoparticles modification for the sensitive detection of human $\alpha$-thrombin. Talanta 2016, 154, 555-559. [CrossRef] [PubMed]

23. Yang, L.; Ning, X.; Xiao, Q.; Chen, K.; Zhou, H. Development and characterization of porous silver-incorporated hydroxyapatite ceramic for separation and elimination of microorganisms. J. Biomed. Mater. Res. Part B Appl. Biomater. 2007, 81, 50-56. [CrossRef] [PubMed]

24. Wan, L.; Zhang, L.; Lei, W.; Zhu, Y.; Zhang, W.; Wang, Y. Novel hybrid organic-inorganic monolithic column containing mesoporous nanoparticles for capillary electrochromatography. Talanta 2012, 98, $277-281$. [CrossRef] [PubMed]

25. El-Safty, S.A.; Hanaoka, T.; Mizukami, F. Stability of highly ordered nanostructures with uniformly cylindrical mesochannels. Acta Mater. 2006, 54, 899-908. [CrossRef]

26. Bai, L.; Wang, J.; Zhang, H.; Liu, S.; Qin, J.; Liu, H. Ionic liquid as porogen in the preparation of a polymer-based monolith for the separation of protein by high performance liquid chromatography. Anal. Methods 2015, 7, 607-613. [CrossRef]

27. Wang, J.; Jiang, X.; Zhang, H.; Liu, S.; Bai, L.; Liu, H. Preparation of a porous polymer monolithic column with an ionic liquid as a porogen and its applications for the separation of small molecules in high performance liquid chromatography. Anal. Methods 2015, 7, 7879-7888. [CrossRef]

28. Sui, R.; Liu, S.; Lajoie, G.A.; Charpentier, P.A. Preparing titania aerogel monolithic chromatography columns using supercritical carbon dioxide. J. Sep. Sci. 2010, 33, 1604-1609. [CrossRef] [PubMed]

29. Wang, J.; Oschatz, M.; Biemelt, T.; Borchardt, L.; Senkovska, I.; Lohe, M.R.; Kaskel, S. Synthesis, characterization, and hydrogen storage capacities of hierarchical porous carbide derived carbon monolith. J. Mater. Chem. 2012, 22, 23893-23899. [CrossRef]

30. Navarro-Pascual-Ahuir, M.; Lerma-García, M.J.; Ramis-Ramos, G.; Simó-Alfonso, E.F.; Herrero-Martínez, J.M. Preparation and evaluation of lauryl methacrylate monoliths with embedded silver nanoparticles for capillary electrochromatography. Electrophoresis 2013, 34, 925-934. [CrossRef] [PubMed]

31. Siouffi, A.-M. Silica gel-based monoliths prepared by the sol-gel method: Facts and figures. J. Chromatogr. A 2003, 1000, 801-818. [CrossRef]

32. Liu, Z.; Ou, J.; Zou, H. Click polymerization for preparation of monolithic columns for liquid chromatography. TrAC Trends Anal. Chem. 2016, 82, 89-99. [CrossRef]

33. Mann, S.; Burkett, S.L.; Davis, S.A.; Fowler, C.E.; Mendelson, N.H.; Sims, S.D.; Walsh, D.; Whilton, N.T. Sol-gel synthesis of organized matter. Chem. Mater. 1997, 9, 2300-2310. [CrossRef]

34. Unger, K.K.; Tanaka, N.; Machtejevas, E. Monolithic Silicas in Separation Science; Wiley-VCH: Weinheim, Germany, 2011; Volume 15, p. 16. 
35. Dong, X.; Dong, J.; Ou, J.; Zhu, Y.; Zou, H. Preparation and evaluation of a vancomycin-immobilized silica monolith as chiral stationary phase for CEC. Electrophoresis 2007, 28, 2606-2612. [CrossRef] [PubMed]

36. Ongkudon, C.M.; Danquah, M.K. Anion exchange chromatography of $4.2 \mathrm{kbp}$ plasmid based vaccine (pcDNA3F) from alkaline lysed E. coli lysate using amino functionalised polymethacrylate conical monolith. Sep. Purif. Technol. 2011, 78, 303-310. [CrossRef]

37. Tian, Y.; Zhong, C.; Fu, E.; Zeng, Z. Novel $\beta$-cyclodextrin derivative functionalized polymethacrylate-based monolithic columns for enantioselective separation of ibuprofen and naproxen enantiomers in capillary electrochromatography. J. Chromatogr. A 2009, 1216, 1000-1007. [CrossRef] [PubMed]

38. Wang, X.; Lin, X.; Xie, Z. Preparation and evaluation of a sulfoalkylbetaine-based zwitterionic monolithic column for cec of polar analytes. Electrophoresis 2009, 30, 2702-2710. [CrossRef] [PubMed]

39. Jiang, Z.; Smith, N.W.; Ferguson, P.D.; Taylor, M.R. Hydrophilic interaction chromatography using methacrylate-based monolithic capillary column for the separation of polar analytes. Anal. Chem. 2007, 79, 1243-1250. [CrossRef] [PubMed]

40. Chan, A.S.; Danquah, M.K.; Agyei, D.; Hartley, P.G.; Zhu, Y. A simple microfluidic chip design for fundamental bioseparation. J. Anal. Methods Chem. 2014, 2014, 175457. [CrossRef] [PubMed]

41. Mallik, R.; Jiang, T.; Hage, D.S. High-performance affinity monolith chromatography: Development and evaluation of human serum albumin columns. Anal. Chem. 2004, 76, 7013-7022. [CrossRef] [PubMed]

42. Hilder, E.F.; Svec, F.; Fréchet, J.M.J. Latex-functionalized monolithic columns for the separation of carbohydrates by micro anion-exchange chromatography. J. Chromatogr. A 2004, 1053, 101-106. [CrossRef]

43. Preinerstorfer, B.; Lubda, D.; Mucha, A.; Kafarski, P.; Lindner, W.; Lämmerhofer, M. Stereoselective separations of chiral phosphinic acid pseudodipeptides by CEC using silica monoliths modified with an anion-exchange-type chiral selector. Electrophoresis 2006, 27, 4312-4320. [CrossRef] [PubMed]

44. Mallik, R.; Hage, D.S. Development of an affinity silica monolith containing human serum albumin for chiral separations. J. Pharm. Biomed. Anal. 2008, 46, 820-830. [CrossRef] [PubMed]

45. Chen, Z.; Hobo, T. Chemically L-phenylalaninamide-modified monolithic silica column prepared by a sol-gel process for enantioseparation of dansyl amino acids by ligand exchange-capillary electrochromatography. Anal. Chem. 2001, 73, 3348-3357. [CrossRef] [PubMed]

46. Moravcová, D.; Planeta, J.; Kahle, V.; Roth, M. Zwitterionic silica-based monolithic capillary columns for isocratic and gradient hydrophilic interaction liquid chromatography. J. Chromatogr. A 2012, 1270, 178-185. [CrossRef] [PubMed]

47. Yu, C.; Xu, M.; Svec, F.; Fréchet, J.M. Preparation of monolithic polymers with controlled porous properties for microfluidic chip applications using photoinitiated free-radical polymerization. J. Polym. Sci. Part A Polym. Chem. 2002, 40, 755-769. [CrossRef]

48. Dong, X.; Wu, R.; Dong, J.; Wu, M.; Zhu, Y.; Zou, H. Polyacrylamide-based monolithic capillary column with coating of cellulose tris(3,5-dimethylphenyl-carbamate) for enantiomer separation in capillary electrochromatography. Electrophoresis 2008, 29, 919-927. [CrossRef] [PubMed]

49. Bragg, W.; Shamsi, S.A. A novel positively charged achiral co-monomer for $\beta$-cyclodextrin monolithic stationary phase: Improved chiral separation of acidic compounds using capillary electrochromatography coupled to mass spectrometry. J. Chromatogr. A 2012, 1267, 144-155. [CrossRef] [PubMed]

50. Zhang, Z.; Wu, M.; Wu, R.a.; Dong, J.; Ou, J.; Zou, H. Preparation of perphenylcarbamoylated $\beta$-cyclodextrin-silica hybrid monolithic column with "one-pot" approach for enantioseparation by capillary liquid chromatography. Anal. Chem. 2011, 83, 3616-3622. [CrossRef] [PubMed]

51. Lin, H.; Ou, J.; Zhang, Z.; Dong, J.; Wu, M.; Zou, H. Facile preparation of zwitterionic organic-silica hybrid monolithic capillary column with an improved "one-pot" approach for hydrophilic-interaction liquid chromatography (HILIC). Anal. Chem. 2012, 84, 2721-2728. [CrossRef] [PubMed]

52. Acquah, C.; Danquah, M.K.; Moy, C.K.S.; Ongkudon, C.M. In-process thermochemical analysis of in situ poly(ethylene glycol methacrylate-co-glycidyl methacrylate) monolithic adsorbent synthesis. J. Appl. Polym. Sci. 2016, 133. [CrossRef]

53. Chambers, S.D.; Holcombe, T.W.; Svec, F.; Fréchet, J.M.J. Porous polymer monoliths functionalized through copolymerization of a C60 fullerene-containing methacrylate monomer for highly efficient separations of small molecules. Anal. Chem. 2011, 83, 9478-9484. [CrossRef] [PubMed]

54. Yan, Q.Z.; Lu, G.D.; Zhang, W.F.; Ma, X.H.; Ge, C.C. Frontal polymerization synthesis of monolithic macroporous polymers. Adv. Funct. Mater. 2007, 17, 3355-3362. [CrossRef] 
55. Feng, Q.; Yan, Q.; Ge, C. Frontal polymerization synthesis and characterization of temperature-and pH-sensitive hydrogels. Colloid Polym. Sci. 2013, 291, 1163-1170. [CrossRef]

56. Beiler, B.; Vincze, Á.; Svec, F.; Sáfrány, Á. Poly(2-hydroxyethyl acrylate-co-ethyleneglycol dimethacrylate) monoliths synthesized by radiation polymerization in a mold. Polymer 2007, 48, 3033-3040. [CrossRef]

57. Shih, Y.-H.; Singco, B.; Liu, W.-L.; Hsu, C.-H.; Huang, H.-Y. A rapid synthetic method for organic polymer-based monoliths in a room temperature ionic liquid medium via microwave-assisted vinylization and polymerization. Green Chem. 2011, 13, 296-299. [CrossRef]

58. Khalil, A.M.; Georgiadou, V.; Guerrouache, M.; Mahouche-Chergui, S.; Dendrinou-Samara, C.; Chehimi, M.M.; Carbonnier, B. Gold-decorated polymeric monoliths: In-situ vs ex-situ immobilization strategies and flow through catalytic applications towards nitrophenols reduction. Polymer 2015, 77, 218-226. [CrossRef]

59. Yao, C.; Qi, L.; Qiao, J.; Zhang, H.; Wang, F.; Chen, Y.; Yang, G. High-performance affinity monolith chromatography for chiral separation and determination of enzyme kinetic constants. Talanta 2010, 82, 1332-1337. [CrossRef] [PubMed]

60. Lee, J.; Gan, H.T.; Latiff, S.M.A.; Chuah, C.; Lee, W.Y.; Yang, Y.-S.; Loo, B.; Ng, S.K.; Gagnon, P. Principles and applications of steric exclusion chromatography. J. Chromatogr. A 2012, 1270, 162-170. [CrossRef] [PubMed]

61. Jiang, T.; Mallik, R.; Hage, D.S. Affinity monoliths for ultrafast immunoextraction. Anal. Chem. 2005, 77, 2362-2372. [CrossRef] [PubMed]

62. Wang, P.G. Monolithic Chromatography and Its Modern Applications; ILM Publications: St Albans, UK, 2010.

63. Pfaunmiller, E.; Paulemond, M.; Dupper, C.; Hage, D. Affinity monolith chromatography: A review of principles and recent analytical applications. Anal. Bioanal. Chem. 2013, 405, 2133-2145. [CrossRef] [PubMed]

64. Hirabayashi, J.; Kasai, K.-I. Applied slalom chromatography improved DNA separation by the use of columns developed for reversed-phase chromatography. J. Chromatogr. A 1996, 722, 135-142. [CrossRef]

65. Peyrin, E.; Caron, C.; Garrel, C.; Ravel, A.; Villet, A.; Grosset, C.; Favier, A. DNA migration regimes in hydrodynamic chromatography and slalom chromatography: Evidence for a transition. Talanta 2001, 55, 291-296. [CrossRef]

66. Andjelkovic, I.; Tran, D.N.; Kabiri, S.; Azari, S.; Markovic, M.; Losic, D. Graphene aerogels decorated with $\alpha$-feooh nanoparticles for efficient adsorption of arsenic from contaminated waters. ACS Appl. Mater. Interfaces 2015, 7, 9758-9766. [CrossRef] [PubMed]

67. Huang, H.; Chen, P.; Zhang, X.; Lu, Y.; Zhan, W. Edge-to-edge assembled graphene oxide aerogels with outstanding mechanical performance and superhigh chemical activity. Small 2013, 9, 1397-1404. [CrossRef] [PubMed]

68. Zhao, H.; Wang, Y.; Cheng, H.; Shen, Y. Graphene oxide decorated monolithic column as stationary phase for capillary electrochromatography. J. Chromatogr. A 2016, 1452, 27-35. [CrossRef] [PubMed]

69. Connolly, D.; Currivan, S.; Paull, B. Polymeric monolithic materials modified with nanoparticles for separation and detection of biomolecules: A review. Proteomics 2012, 12, 2904-2917. [CrossRef] [PubMed]

70. Rechberger, F.; Städler, R.; Tervoort, E.; Niederberger, M. Strategies to improve the electrical conductivity of nanoparticle-based antimony-doped tin oxide aerogels. J. Sol-Gel Sci. Technol. 2016, 80, 660-666. [CrossRef]

71. Hu, W.; Hong, T.; Gao, X.; Ji, Y. Applications of nanoparticle-modified stationary phases in capillary electrochromatography. TrAC Trends Anal. Chem. 2014, 61, 29-39. [CrossRef]

72. Carrasco-Correa, E.J.; Ramis-Ramos, G.; Herrero-Martínez, J.M. Hybrid methacrylate monolithic columns containing magnetic nanoparticles for capillary electrochromatography. J. Chromatogr. A 2015, 1385, 77-84. [CrossRef] [PubMed]

73. Alla, A.J.; Stine, K.J. Development of monolithic column materials for the separation and analysis of glycans. Chromatography 2015, 2, 20-65. [CrossRef]

74. Delgado, J.L.; Herranz, M.Á.; Martin, N. The nano-forms of carbon. J. Mater. Chem. 2008, 18, 1417-1426. [CrossRef]

75. Bhunia, S.K.; Saha, A.; Maity, A.R.; Ray, S.C.; Jana, N.R. Carbon nanoparticle-based fluorescent bioimaging probes. Sci. Rep. 2013, 3, 1473. [CrossRef] [PubMed]

76. Dinadayalane, T.; Leszczynski, J. Remarkable diversity of carbon-carbon bonds: Structures and properties of fullerenes, carbon nanotubes, and graphene. Struct. Chem. 2010, 21, 1155-1169. [CrossRef] 
77. Lam, C.-W.; James, J.T.; McCluskey, R.; Arepalli, S.; Hunter, R.L. A review of carbon nanotube toxicity and assessment of potential occupational and environmental health risks. Crit. Rev. Toxicol. 2006, 36, 189-217. [CrossRef] [PubMed]

78. Kojima, A.; Hyon, C.K.; Kamimura, T.; Maeda, M.; Matsumoto, K. Protein sensor using carbon nanotube field effect transistor. Jpn. J. Appl. Phys. 2005, 44, 1596. [CrossRef]

79. Li, Y.; Chen, Y.; Xiang, R.; Ciuparu, D.; Pfefferle, L.D.; Horváth, C.; Wilkins, J.A. Incorporation of single-wall carbon nanotubes into an organic polymer monolithic stationary phase for $\mu$-HPLC and capillary electrochromatography. Anal. Chem. 2005, 77, 1398-1406. [CrossRef] [PubMed]

80. Navarro-Pascual-Ahuir, M.; Lucena, R.; Cárdenas, S.; Ramis-Ramos, G.; Valcárcel, M.; Herrero-Martínez, J.M. UV-polymerized butyl methacrylate monoliths with embedded carboxylic single-walled carbon nanotubes for cec applications. Anal. Bioanal. Chem. 2014, 406, 6329-6336. [CrossRef] [PubMed]

81. André, C.; Lenancker, G.; Guillaume, Y.C. Non-covalent functionalisation of monolithic silica for the development of carbon nanotube hplc stationary phases. Talanta 2012, 99, 580-585. [CrossRef] [PubMed]

82. Mayadunne, E.; El Rassi, Z. Facile preparation of octadecyl monoliths with incorporated carbon nanotubes and neutral monoliths with coated carbon nanotubes stationary phases for HPLC of small and large molecules by hydrophobic and $\pi-\pi$ interactions. Talanta 2014, 129, 565-574. [CrossRef] [PubMed]

83. Chambers, S.D.; Svec, F.; Fréchet, J.M. Incorporation of carbon nanotubes in porous polymer monolithic capillary columns to enhance the chromatographic separation of small molecules. J. Chromatogr. A 2011, 1218, 2546-2552. [CrossRef] [PubMed]

84. Zhou, C.; Du, Z.; Li, G.; Zhang, Y.; Cai, Z. Oligomers matrix-assisted dispersion of high content of carbon nanotubes into monolithic column for online separation and enrichment of proteins from complex biological samples. Analyst 2013, 138, 5783-5790. [CrossRef] [PubMed]

85. André, C.; Agiovlasileti, D.; Guillaume, Y.C. Peculiarities of a novel bioenzymatic reactor using carbon nanotubes as enzyme activity enhancers: Application to arginase. Talanta 2011, 85, 2703-2706. [CrossRef] [PubMed]

86. Liu, Q.; Shi, J.; Jiang, G. Application of graphene in analytical sample preparation. TrAC Trends Anal. Chem. 2012, 37, 1-11. [CrossRef]

87. Barber, A.H.; Cohen, S.R.; Wagner, H.D. Static and dynamic wetting measurements of single carbon nanotubes. Phys. Rev. Lett. 2004, 92, 186103. [CrossRef] [PubMed]

88. Zhao, W.; Song, C.; Pehrsson, P.E. Water-soluble and optically pH-sensitive single-walled carbon nanotubes from surface modification. J. Am. Chem. Soc. 2002, 124, 12418-12419. [CrossRef] [PubMed]

89. Zhang, L.-S.; Gao, S.-P.; Huang, Y.-P.; Liu, Z.-S. Green synthesis of polymer monoliths incorporated with carbon nanotubes in room temperature ionic liquid and deep eutectic solvents. Talanta 2016, 154, 335-340. [CrossRef] [PubMed]

90. Tang, S.; Guo, Y.; Xiong, C.; Liu, S.; Liu, X.; Jiang, S. Nanoparticle-based monoliths for chromatographic separations. Analyst 2014, 139, 4103-4117. [CrossRef] [PubMed]

91. Kubo, T.; Murakami, Y.; Tsuzuki, M.; Kobayashi, H.; Naito, T.; Sano, T.; Yan, M.; Otsuka, K. Unique separation behavior of a C60 fullerene-bonded silica monolith prepared by an effective thermal coupling agent. Chemistry 2015, 21, 18095-18098. [CrossRef] [PubMed]

92. Hong, T.; Yang, X.; Xu, Y.; Ji, Y. Recent advances in the preparation and application of monolithic capillary columns in separation science. Anal. Chim. Acta 2016, 931, 1-24. [CrossRef] [PubMed]

93. Tong, S.; Liu, Q.; Li, Y.; Zhou, W.; Jia, Q.; Duan, T. Preparation of porous polymer monolithic column incorporated with graphene nanosheets for solid phase microextraction and enrichment of glucocorticoids. J. Chromatogr. A 2012, 1253, 22-31. [CrossRef] [PubMed]

94. Wang, M.-M.; Yan, X.-P. Fabrication of graphene oxide nanosheets incorporated monolithic column via one-step room temperature polymerization for capillary electrochromatography. Anal. Chem. 2011, 84, $39-44$. [CrossRef] [PubMed]

95. Han, Q.; Liang, Q.; Zhang, X.; Yang, L.; Ding, M. Graphene aerogel based monolith for effective solid-phase extraction of trace environmental pollutants from water samples. J. Chromatogr. A 2016, 1447, $39-46$. [CrossRef] [PubMed]

96. Zhao, Y.; Hu, C.; Hu, Y.; Cheng, H.; Shi, G.; Qu, L. A versatile, ultralight, nitrogen-doped graphene framework. Angew. Chem. 2012, 124, 11533-11537. [CrossRef] 
97. Das, R.; Ghosh, S.; Chowdhury, I.H.; Naskar, M.K. Biogenic silver nanoparticle impregnated hollow mesoporous silicalite-1: An efficient catalyst for p-nitrophenol reduction. New J. Chem. 2016, 40, 50-53. [CrossRef]

98. Iravani, S.; Korbekandi, H.; Mirmohammadi, S.; Zolfaghari, B. Synthesis of silver nanoparticles: Chemical, physical and biological methods. Res. Pharm. Sci. 2014, 9, 385. [PubMed]

99. Zhu, Y.; Morisato, K.; Li, W.; Kanamori, K.; Nakanishi, K. Synthesis of silver nanoparticles confined in hierarchically porous monolithic silica: A new function in aromatic hydrocarbon separations. ACS Appl. Mater. Interfaces 2013, 5, 2118-2125. [CrossRef] [PubMed]

100. Hashemi-Nasab, R.; Mirabedini, S. Effect of silica nanoparticles surface treatment on in situ polymerization of styrene-butyl acrylate latex. Prog. Org. Coat. 2013, 76, 1016-1023. [CrossRef]

101. Huang, J.; Li, Q.; Sun, D.; Lu, Y.; Su, Y.; Yang, X.; Wang, H.; Wang, Y.; Shao, W.; He, N. Biosynthesis of silver and gold nanoparticles by novel sundried cinnamomum camphora leaf. Nanotechnology 2007, 18, 105104. [CrossRef]

102. Zhu, Y.; Morisato, K.; Hasegawa, G.; Moitra, N.; Kiyomura, T.; Kurata, H.; Kanamori, K.; Nakanishi, K. High-performance liquid chromatography separation of unsaturated organic compounds by a monolithic silica column embedded with silver nanoparticles. J. Sep. Sci. 2015, 38, 2841-2847. [CrossRef] [PubMed]

103. Yu, H.; Zhu, Y.; Yang, H.; Nakanishi, K.; Kanamori, K.; Guo, X. Facile preparation of silver nanoparticles homogeneously immobilized in hierarchically monolithic silica using ethylene glycol as reductant. Dalton Trans. 2014, 43, 12648-12656. [CrossRef] [PubMed]

104. Liu, J.; White, I.; DeVoe, D.L. Nanoparticle-functionalized porous polymer monolith detection elements for surface-enhanced raman scattering. Anal. Chem. 2011, 83, 2119-2124. [CrossRef] [PubMed]

105. Pan, Y.; Guo, X.; Zhu, J.; Wang, X.; Zhang, H.; Kang, Y.; Wu, T.; Du, Y. A new sers substrate based on silver nanoparticle functionalized polymethacrylate monoliths in a capillary, and it application to the trace determination of pesticides. Microchim. Acta 2015, 182, 1775-1782. [CrossRef]

106. Aydoğan, C.; El Rassi, Z. Monolithic stationary phases with incorporated fumed silica nanoparticles. Part I. Polymethacrylate-based monolithic column with incorporated bare fumed silica nanoparticles for hydrophilic interaction liquid chromatography. J. Chromatogr. A 2016, 1445, 55-61. [CrossRef] [PubMed]

107. Aydoğan, C.; El Rassi, Z. Monolithic stationary phases with incorporated fumed silica nanoparticles. Part II. Polymethacrylate-based monolithic column with "covalently" incorporated modified octadecyl fumed silica nanoparticles for reversed-phase chromatography. J. Chromatogr. A 2016, 1445, 62-67. [CrossRef] [PubMed]

108. Xu, Y.; Cao, Q.; Svec, F.; Frechet, J.M. Porous polymer monolithic column with surface-bound gold nanoparticles for the capture and separation of cysteine-containing peptides. Anal. Chem. 2010, 82, 3352-3358. [CrossRef] [PubMed]

109. Ngo, Y.H.; Then, W.L.; Shen, W.; Garnier, G. Gold nanoparticles paper as a sers bio-diagnostic platform. J. Colloid Interface Sci. 2013, 409, 59-65. [CrossRef] [PubMed]

110. Ma, X.; Truong, P.L.; Anh, N.H.; Sim, S.J. Single gold nanoplasmonic sensor for clinical cancer diagnosis based on specific interaction between nucleic acids and protein. Biosens. Bioelectron. 2015, 67, 59-65. [CrossRef] [PubMed]

111. Oo, S.Z.; Silva, G.; Carpignano, F.; Noual, A.; Pechstedt, K.; Mateos, L.; Grant-Jacob, J.A.; Brocklesby, B.; Horak, P.; Charlton, M. A nanoporous gold membrane for sensing applications. Sens. Bio-Sens. Res. 2016, 7, 133-140. [CrossRef] [PubMed]

112. Nazirov, A.; Pestov, A.; Privar, Y.; Ustinov, A.; Modin, E.; Bratskaya, S. One-pot green synthesis of luminescent gold nanoparticles using imidazole derivative of chitosan. Carbohydr. Polym. 2016, 151, 649-655. [CrossRef] [PubMed]

113. Leung, K. Polyethylene glycol-coated gold nanoshells conjugated with anti-VCAM-1 antibody. Available online: https:/ /www.ncbi.nlm.nih.gov/books/NBK137861/ (accessed on 16 May 2013).

114. Connolly, D.; Twamley, B.; Paull, B. High-capacity gold nanoparticle functionalised polymer monoliths. Chem. Commun. 2010, 46, 2109-2111. [CrossRef] [PubMed]

115. Zhao, Q.; Li, X.-F.; Le, X.C. Aptamer-modified monolithic capillary chromatography for protein separation and detection. Anal. Chem. 2008, 80, 3915-3920. [CrossRef] [PubMed]

116. Deng, N.; Liang, Z.; Liang, Y.; Sui, Z.; Zhang, L.; Wu, Q.; Yang, K.; Zhang, L.; Zhang, Y. Aptamer modified organic-inorganic hybrid silica monolithic capillary columns for highly selective recognition of thrombin. Anal. Chem. 2012, 84, 10186-10190. [CrossRef] [PubMed] 
117. Vergara-Barberán, M.; Lerma-García, M.J.; Simó-Alfonso, E.F.; Herrero-Martínez, J.M. Solid-phase extraction based on ground methacrylate monolith modified with gold nanoparticles for isolation of proteins. Anal. Chim. Acta 2016, 917, 37-43. [CrossRef] [PubMed]

118. Zhang, J.; Chen, G.; Tian, M.; Li, R.; Quan, X.; Jia, Q. A novel organic-inorganic hybrid monolithic column prepared in-situ in a microchip and its application for the determination of 2-amino-4-chlorophenol in chlorzoxazone tablets. Talanta 2013, 115, 801-805. [CrossRef] [PubMed]

119. Li, W.-J.; Zhou, X.; Tong, S.-S.; Jia, Q. Poly( $N$-isopropylacrylamide-co- $N, N^{\prime}$-methylene bisacrylamide) monolithic column embedded with $\gamma$-alumina nanoparticles microextraction coupled with high-performance liquid chromatography for the determination of synthetic food dyes in soft drink samples. Talanta 2013, 105, 386-392. [CrossRef] [PubMed]

120. Sakwa-Novak, M.A.; Yoo, C.J.; Tan, S.; Rashidi, F.; Jones, C.W. Poly(ethylenimine)-functionalized monolithic alumina honeycomb adsorbents for $\mathrm{CO}_{2}$ capture from air. ChemSusChem 2016, 9, 1859-1868. [CrossRef] [PubMed]

121. Li, W.; Zhou, X.; Ye, J.; Jia, Q. Development of a $\gamma$-alumina-nanoparticle-functionalized porous polymer monolith for the enrichment of sudan dyes in red wine samples. J. Sep. Sci. 2013, 36, 3330-3337. [CrossRef] [PubMed]

122. Wei, F.; Fan, J.; Zheng, M.M.; Feng, Y.Q. Combining poly(methacrylic acid-co-ethylene glycol dimethacrylate) monolith microextraction and octadecyl phosphonic acid-modified zirconia-coated CEC with field-enhanced sample injection for analysis of antidepressants in human plasma and urine. Electrophoresis 2010, 31, 714-723. [CrossRef] [PubMed]

123. Schafer, W.A.; Carr, P.W.; Funkenbusch, E.; Parson, K. Physical and chemical characterization of a porous phosphate-modified zirconia substrate. J. Chromatogr. A 1991, 587, 137-147. [CrossRef]

124. Hoth, D.C.; Rivera, J.G.; Colón, L.A. Metal oxide monolithic columns. J. Chromatogr. A 2005, 1079, $392-396$. [CrossRef] [PubMed]

125. Randon, J.; Huguet, S.; Piram, A.; Puy, G.; Demesmay, C.; Rocca, J.-L. Synthesis of zirconia monoliths for chromatographic separations. J. Chromatogr. A 2006, 1109, 19-25. [CrossRef] [PubMed]

126. Kumar, A.P.; Park, J.H. Enantioseparation on cellulose dimethylphenylcarbamate-modified zirconia monolithic columns by reversed-phase capillary electrochromatography. J. Chromatogr. A 2010, 1217, 4494-4500. [CrossRef] [PubMed]

127. Kumar, A.P.; Park, J.H. Chiral separation of basic compounds on a cellulose 3,5-dimethylphenylcarbamate-coated zirconia monolithin basic eluents by capillary electrochromatography. J. Chromatogr. A 2011, 1218, 6548-6553. [CrossRef] [PubMed]

128. Park, J.-M.; Park, J.H. Enantiomer separations of basic chiral compounds by capillary electrochromatography on a phosphated $\beta$-cyclodextrin-modified zirconia monolith. J. Chromatogr. A 2014, 1339, 229-233. [CrossRef] [PubMed]

129. Sui, R.; Rizkalla, A.S.; Charpentier, P.A. Direct synthesis of zirconia aerogel nanoarchitecture in supercritical $\mathrm{CO}_{2}$. Langmuir ACS J. Surf. Colloids 2006, 22, 4390-4396. [CrossRef] [PubMed]

130. Randon, J.; Huguet, S.; Demesmay, C.; Berthod, A. Zirconia based monoliths used in hydrophilic-interaction chromatography for original selectivity of xanthines. J. Chromatogr. A 2010, 1217, 1496-1500. [CrossRef] [PubMed]

131. Tran, L.N.; Park, J.H. Enantiomer separation of acidic chiral compounds on a quinine-silica/zirconia hybrid monolith by capillary electrochromatography. J. Chromatogr. A 2015, 1396, 140-147. [CrossRef] [PubMed]

132. Tran, L.N.; Dixit, S.; Park, J.H. Enantioseparation of basic chiral compounds on a clindamycin phosphate-silica/zirconia hybrid monolith by capillary electrochromatography. J. Chromatogr. A 2014, 1356, 289-293. [CrossRef] [PubMed]

133. Zhao, N.; Pan, D.; Nie, W.; Ji, X. Two-phase synthesis of shape-controlled colloidal zirconia nanocrystals and their characterization. J. Am. Chem. Soc. 2006, 128, 10118-10124. [CrossRef] [PubMed]

134. Joo, J.; Yu, T.; Kim, Y.W.; Park, H.M.; Wu, F.; Zhang, J.Z.; Hyeon, T. Multigram scale synthesis and characterization of monodisperse tetragonal zirconia nanocrystals. J. Am. Chem. Soc. 2003, 125, 6553-6557. [CrossRef] [PubMed]

135. Pinna, N.; Garnweitner, G.; Antonietti, M.; Niederberger, M. Non-aqueous synthesis of high-purity metal oxide nanopowders using an ether elimination process. Adv. Mater. 2004, 16, 2196-2200. [CrossRef] 
136. Liu, C.; Hajagos, T.J.; Chen, D.; Chen, Y.; Kishpaugh, D.; Pei, Q. Efficient one-pot synthesis of colloidal zirconium oxide nanoparticles for high-refractive-index nanocomposites. ACS Appl. Mater. Interfaces 2016, 8 , 4795-4802. [CrossRef] [PubMed]

137. Hou, C.; Ma, J.; Tao, D.; Shan, Y.; Liang, Z.; Zhang, L.; Zhang, Y. Organic-inorganic hybrid silica monolith based immobilized titanium ion affinity chromatography column for analysis of mitochondrial phosphoproteome. J. Proteome Res. 2010, 9, 4093-4101. [CrossRef] [PubMed]

138. Krenkova, J.; Foret, F. Nanoparticle-modified monolithic pipette tips for phosphopeptide enrichment. Anal. Bioanal. Chem. 2013, 405, 2175-2183. [CrossRef] [PubMed]

139. Smirnov, K.N.; Dyatchkov, I.A.; Telnov, M.V.; Pirogov, A.V.; Shpigun, O.A. Effect of monomer mixture composition on structure and chromatographic properties of poly(divinylbenzeneco-ethylvinylbenzene-co-2-hydroxyethyl methacrylate) monolithic rod columns for separation of small molecules. J. Chromatogr. A 2011, 1218, 5010-5019. [CrossRef] [PubMed]

140. Černigoj, U.; Gašperšič, J.; Fichtenbaum, A.; Lendero Krajnc, N.; Vidič, J.; Mitulović, G.; Štrancar, A. Titanium dioxide nanoparticle coating of polymethacrylate-based chromatographic monoliths for phosphopetides enrichment. Anal. Chim. Acta 2016, 942, 146-154. [CrossRef] [PubMed]

141. Sang, L.; Zhao, Y.; Burda, C. $\mathrm{TiO}_{2}$ nanoparticles as functional building blocks. Chem. Rev. 2014, 114, 9283-9318. [CrossRef] [PubMed]

142. Chen, Y.; Yi, Y.; Brennan, J.D.; Brook, M.A. Development of macroporous titania monoliths using a biocompatible method. Part 1: Material fabrication and characterization. Chem. Mater. 2006, 18, 5326-5335. [CrossRef]

143. Long, T.; Xu, L.; Zhang, T.; Wang, Y. Facile synthesis of titania monolith and the investigation of its photocatalytic activity. Mater. Manuf. Process. 2014, 29, 743-747. [CrossRef]

144. Yao, B.; Zhang, L. Preparation and characterization of mesoporous titania gel-monolith. J. Mater. Sci. 1999, 34, 5983-5987. [CrossRef]

145. Konishi, J.; Fujita, K.; Nakanishi, K.; Hirao, K. Phase-separation-induced titania monoliths with well-defined macropores and mesostructured framework from colloid-derived sol-gel systems. Chem. Mater. 2006, 18, 864-866. [CrossRef]

146. Konishi, J.; Fujita, K.; Nakanishi, K.; Hirao, K. Monolithic $\mathrm{TiO}_{2}$ with controlled multiscale porosity via a template-free sol-gel process accompanied by phase separation. Chem. Mater. 2006, 18, 6069-6074. [CrossRef]

147. Ren, J.; Du, Z.J.; Zhang, C.; Li, H.Q. Macroporous titania monolith prepared via sol-gel process with polymer foam as the template. Chin. J. Chem. 2006, 24, 955-960. [CrossRef]

148. Asri, R.; Harun, W.; Hassan, M.; Ghani, S.; Buyong, Z. A review of hydroxyapatite-based coating techniques: Sol-gel and electrochemical depositions on biocompatible metals. J. Mech. Behav. Biomed. Mater. 2016, 57, 95-108. [CrossRef] [PubMed]

149. Yu, S.; Geng, J.; Zhou, P.; Wang, J.; Chen, X.; Hu, J. New hydroxyapatite monolithic column for DNA extraction and its application in the purification of bacillus subtilis crude lysate. J. Chromatogr. A 2008, 1183, 29-37. [CrossRef] [PubMed]

150. Krenkova, J.; Lacher, N.A.; Svec, F. Control of selectivity via nanochemistry: Monolithic capillary column containing hydroxyapatite nanoparticles for separation of proteins and enrichment of phosphopeptides. Anal. Chem. 2010, 82, 8335-8341. [CrossRef] [PubMed]

151. Armatas, G.; Kanatzidis, M. Mesostructured germanium with cubic pore symmetry. Nature 2006, 441, 1122-1125. [CrossRef] [PubMed]

152. Zou, X.; Conradsson, T.; Klingstedt, M.; Dadachov, M.S.; O'Keeffe, M. A mesoporous germanium oxide with crystalline pore walls and its chiral derivative. Nature 2005, 437, 716-719. [CrossRef] [PubMed]

153. Peskov, M.; Schwingenschlögl, U. Photophysical properties of open-framework germanates templated by nickel complexes. Phys. Chem. Chem. Phys. 2014, 16, 10891-10896. [CrossRef] [PubMed]

154. Akama, Y.; Kanno, H. Liquid chromatographie separation of polycyclic aromatic hydrocarbons with cerium (IV) oxide as packing material. Anal. Chim. Acta 1995, 309, 153-156. [CrossRef]

155. Akama, $\mathrm{Y}$. Use of cerium oxide $\left(\mathrm{CeO}_{2}\right)$ as a packing material for the chromatographic separation of $\mathrm{C} 60$ and C70 fullerenes. Talanta 1995, 42, 1943-1946. [CrossRef]

156. Caputo, F.; De Nicola, M.; Sienkiewicz, A.; Giovanetti, A.; Bejarano, I.; Licoccia, S.; Traversa, E.; Ghibelli, L. Cerium oxide nanoparticles, combining antioxidant and UV shielding properties, prevent UV-induced cell damage and mutagenesis. Nanoscale 2015, 7, 15643-15656. [CrossRef] [PubMed] 
157. Kumar, R.; Gokulakrishnan, N.; Kumar, R.; Krishna, V.M.; Saravanan, A.; Supriya, S.; Somanathan, T. Can be a bimetal oxide $\mathrm{ZnO}-\mathrm{MgO}$ nanoparticles anticancer drug carrier and deliver? Doxorubicin adsorption/release study. J. Nanosci. Nanotechnol. 2015, 15, 1543-1553. [CrossRef] [PubMed]

158. Huang, L.; Li, D.; Lin, Y.; Evans, D.G.; Duan, X. Influence of nano-mgo particle size on bactericidal action againstbacillus subtilis var. Niger. Chin. Sci. Bull. 2005, 50, 514-519. [CrossRef]

159. Rajagopalan, S.; Koper, O.; Decker, S.; Klabunde, K.J. Nanocrystalline metal oxides as destructive adsorbents for organophosphorus compounds at ambient temperatures. Chem. A 2002, 8, 2602-2607. [CrossRef]

160. Moussavi, G.; Mahmoudi, M. Removal of azo and anthraquinone reactive dyes from industrial wastewaters using mgo nanoparticles. J. Hazard. Mater. 2009, 168, 806-812. [CrossRef] [PubMed]

161. Lee, M.; Zine, N.; Baraket, A.; Zabala, M.; Campabadal, F.; Caruso, R.; Trivella, M.G.; Jaffrezic-Renault, N.; Errachid, A. A novel biosensor based on hafnium oxide: Application for early stage detection of human interleukin-10. Sens. Actuators B 2012, 175, 201-207. [CrossRef]

162. Kumar, S.; Kumar, S.; Tiwari, S.; Augustine, S.; Srivastava, S.; Yadav, B.K.; Malhotra, B.D. Highly sensitive protein functionalized nanostructured hafnium oxide based biosensing platform for non-invasive oral cancer detection. Sens. Actuators B 2016, 235, 1-10. [CrossRef]

(C) 2017 by the authors; licensee MDPI, Basel, Switzerland. This article is an open access article distributed under the terms and conditions of the Creative Commons Attribution (CC-BY) license (http://creativecommons.org/licenses/by/4.0/). 